\title{
Elementary Forms and the cultural Durkheim
}

Filipe Carreira da Silva (ICS-UL)/Mónica Brito Vieira (York University)

\section{Introduction}

Who reads Emile Durkheim's Elementary Forms of Religious Life?

In 1970, very few sociologists in America did. ${ }^{1}$ Today, Elementary Forms is Durkheim's most influential book for sociologists in America and elsewhere. Elementary Forms became the central totem of culturalist readings of the French master, helping transform "Durkheim," once the master analyst of modernization, into the "cultural Durkheim" celebrated in the pages of national newspapers for his sociology of moral life that helps us become more aware of the myths and beliefs that brings us together as a community. ${ }^{2}$ Paul Vogt is certainly right when he says that "knowledge of Durkheim and his books is a full part of the definition of what a sociologist is in America" (1993: 227), but this evades the more important question of why Elementary Forms became synonymous with Durkheim in the late twentieth century but not before.

In this chapter we try to answer this question by following Durkheim's last book, first published in 1912 under the title Les formes élémentaires de la vie religieuse and translated into English in 1915 as Elementary Forms of the Religious Life (hereafter, Formes and Elementary Forms respectively). While certainly a sociological treatise on religion, focused on the case of totemism in Australia, where some even found the promise of a positive scientific inquiry as "religion is real," Elementary 
Forms has also been read as holding at its core the vision of a more hermeneutic and culturalist model of secular society. We explore these changes in meaning of the book (and, with it, of its author and the sociological project associated with his name) by analyzing the dialectic between form and content through the actions of a number of key human agents. All these agents share the same orientation towards the book as a meaning-making outlet. Given their cultural orientations, material interests and institutional affiliations, however, these agents not only collaborate or reflect upon but actively fight one another as to what the work stands for. The politics of Elementary Forms becomes ever more salient in key historical junctures, as this collective of agents intervenes either in the text and its material form, or on the text through critical reviews or commentary.

The author occupies a central position in this collective of agents. Our interest resides in examining how Durkheim's theorizing about religion developed as he worked on this editorial project. Durkheim's authorial control over the work, however, was never absolute. As much is clear from the case of the translation into English, a project triggered and led not by him, but by the translator, Joseph Ward Swain, in conjunction with the editor, Cecil A. Reynolds, with Durkheim relegated to the position of consultant of the translation work and main editorial decisions. Such a focus on the figure of the editor, whose commercial motivation is often entangled with noncommercial considerations, will lead us to consider the role of publishing houses more generally. In the case of Elementary Forms, the Anglo-American collaboration between Allen and Unwin in the UK and the Free Press in the United States, will be shown to have played a key role in supporting this editorial project throughout most of the twentieth century. Publishers are closely entwined with another type of agent, translators. In fact, the catalogues of these two publishers include the two first English 
translations of Elementary Forms: both the original Swain translation and the new translation of Elementary Forms by Karen Fields of 1995 have come out in the United States as a result of this collaboration. Besides authors, editors, and translators there is yet another of agent whose actions are oriented towards the book. Commentators offer readings of the text, often exploring in creative ways the world-making potentials of books. However, because typically they are not directly involved in the politics of the book, those narrowly following the book can neglect commentators. As we will try to show by reference to the case of Durkheim's Elementary Forms, such neglect can entail a serious limitation in our understanding of the struggles over the meaning of the work.

In what follows, we will try to show the extent to which the latest iteration of these struggles was shaped by the actions of one commentator - Jeffrey C. Alexander. Our choice is justified by the fact that Alexander's writings and teaching have not only performed a key role in proposing a new reading of Durkheim's work, but also deal explicitly with the processes of canon-formation of the discipline in general. Alexander is thus a particularly self-conscious agent, whose efforts in putting forth a new research program can be construed as part and parcel of his more abstract, metatheoretical reflections about how disciplines deal with their past.

\section{Alexander's cultural Durkheim}

Before Alexander, of course, there was Parsons. The voluntarist theory of action developed by Talcott Parsons in The Structure of Social Action (1937) as an alternative to the utilitarian model of society, and before that in his doctoral dissertation on Sombart and Weber (1927/1928-29), serves as the general background theme for Alexander's reading of Elementary Forms in his 4-volume Theoretical Logic in 
Sociology (1982-83). In the second volume, which is dedicated to Marx and Durkheim, Elementary Forms is depicted as the most accomplished expression of Durkheim's "voluntaristic theory of order." (1982: 469) This conclusion is the outcome of one of the most exigent exegesis ever performed of Durkheim's writings, and also one of the most productive as far as an empirical research program is concerned. Today's cultural Durkheim is the direct result of this endeavor.

Like Structure 50 years before, Theoretical Logic is an exercise in theoretical synthesis. ${ }^{3}$ It is a monumental effort aimed at producing a synthesis of the main contributions of a number of seminal thinkers to one central problem, in this case, the problem of how action relates to order. The interpretation of each thinker is framed by this general goal. Durkheim's purported movement from the materialist sociological theory in Division of Labor in Society (1893) toward an idealist, subjective and spiritual model after the mid-1890s is presented as Alexander's demonstration of the thesis that one can find in the late Durkheim a seminal contribution to the timeless problem of action and order. One direct consequence of this interpretation is a dramatic change in the relative position of Elementary Forms in Durkheim's oeuvre.

According to Alexander, there is not one but two Durkheims. There is the materialist Durkheim of the middle-period work and there is mature idealist Durkheim. Separating these two Durkheims is a key intellectual breakthrough, which he reconstructs by means of an exhaustive analysis of all of Durkheim's writings and personal correspondence. ${ }^{4}$ If properly understood, this breakthrough promises to offer us a valuable alternative to the dominant utilitarian, positivist models in the social sciences. Durkheim's crucial shift from materialism to idealism occurs right after the publication of Division of Labor in 1893, which concluded with an endorsement of an instrumental explanation of the nature of modern law and socialist regulation, and 
culminates with Suicide, completed in 1896 and published the following year. In less than three years, Durkheim moves decisively toward subjectivity. As textual evidence of this shift Alexander offers two brief review articles published in the same year as Division of Labor, the articles written in 1894 that were to be published as The Rules of Sociological Method (1895), as well as the 1894-95 lectures on socialism and Suicide. In these writings, Alexander contends, we find overwhelming evidence that Durkheim has "effectively reversed the logic of his earlier work" and "has embarked upon an idealist path." (1982: 220)

Alexander reconceives Durkheim's sociology of religion in light of this crucial shift. It was the "momentum created by this earlier shift that led him to find in the anthropology of religion the more voluntaristic vocabulary he so urgently sought. The subjective model of association was already in place by early 1894.” (1982: 236) Durkheim's basic explanation of religion is thus a direct consequence of his more general, presuppositional abandonment of materialism over idealism, rather than being a separate line of research (Lukes 1973). Crucially it does not evolve in any significant way between 1898, when Durkheim writes his first essay on religion, and 1912, the date of publication of Elementary Forms. The only change is the degree of sophistication of the theory and the wealth of empirical data employed to support it. The essential insight remains the same. Elementary Forms emerges from Alexander's reading as Durkheim's final, most accomplished statement on religion certainly, but, more fundamentally, on a voluntarist theory of secular life.

As with Parsons's, Alexander's synthesis has given origin to an empirical research program aimed at applying the lessons of the classics in the study of contemporary social and political life. In the years subsequent to the publication of Theoretical Logic, Alexander makes use of two books to position his newly found late 
Durkheimian program vis-à-vis both the sociological establishment of the 1980s and contemporary intellectual movements, namely cultural studies. The first is Twenty Lectures (1987), a popular textbook. There is no chapter on Durkheim per se, but the chapter on the hermeneutic tradition covers some of the themes and authors Alexander will later present in the genealogy of structuralism he will present to legitimize cultural sociology. Partly because of its pedagogic intent, Twenty Lectures offers a pluralist narrative of the sociological tradition, in which it is a clear departure from Theoretical Logic. But his admiration for Parsons's synthetic efforts remains unchallenged. The anti-Parsonian movement of the 1970s, encompassing a disjointed combination of symbolic interactionists, conflict sociologists, and the like, had become the establishment of the 1980s sociology. As a result, sociology could no longer conceive of culture as an independent causal variable. The time was ripe for a cultural sociology. This is the theme of his next book, Durkheimian Sociology (1988), a collection of essays for which Elementary Forms "functions as a model for explaining central processes in secular social life.” (Alexander 1988: 11)

From this point onwards, Alexander will cease to act as a commentator of the sociological tradition at large and will focus exclusively in exploring the "secular relevance of Durkheim's religious sociology.” (1988: 193; see also Alexander and Smith 2005) The central goal has been to develop a strong program in "cultural sociology" (Alexander and Smith 2001) as an alternative to so-called "materialist" approaches such as Pierre Bourdieu's "sociology of culture." Most of the themes explored by the strong program in cultural sociology of Alexander and his associates are explicitly political and deal with representation. Always with Elementary Forms in the background, representation is shown to provide the crucial mediation between individual interaction and social order, i.e. to be the process through which subjectivity 
gets transferred from immediate association to the ideational order that governs future acts in such varied cases such as the Watergate scandal, the civil sphere, cultural trauma, the election of President Obama or the Egyptian democratic revolution of 2011 (e.g. Alexander 2010). ${ }^{5}$ This is, in brief, the origin of the "cultural Durkheim," arguably the most influential appropriation of the French master in the social sciences today and one of the few explicitly oriented towards the exploration of the implications of Durkheim's sociology of religion for the study of secular phenomena.

Yet the crucial "shift toward subjectivity" (Alexander 1988: 15, n. 1) upon which the "cultural Durkheim" is premised is anything but obvious. In fact, it has been the point of contention ever since it was first suggested. To this day scholarship on Durkheim has been divided upon those who emphasize continuity in his intellectual development, typically around a central theme or preoccupation (e.g. Aron 1967), and those who discern different developmental phases in this process, although there is hardly any agreement about the exact duration of these phases, their content, and the reasons for their origin and conclusion. In itself, then, Alexander's discontinuist account of Durkheim's intellectual development is not uncommon among Durkheimian scholars. Less convincing is the specific explanation of Durkheim's crucial shift from materialism to idealism, especially in light of Alexander's own premises. Indeed, the externalist explanation provided by Alexander to account for its "causes" - a combination of personal circumstances (the death of Durkheim's father in February 1896) ${ }^{6}$ and general social developments such as "the renewal of Marxism in French society" stimulated in part by "increased class conflict in the political and economic realms" and the "great upsurge in strikes and worker protests" (1982: 231) - as Alexander concedes in a footnote, "is not an estimation based on hard evidence." (1982: 472) In fact, such explanation falls short of identifying the reasons why, and the 
processes whereby, such external factors produce the effects they purportedly do. More important, such an externalist account for Durkheim's theorizing seems to be fundamentally at odds with Alexander's own critique of sociological materialism. In fact, there is no good reason for not treating theorizing as any other social practice and study it accordingly. Indeed, if one explores this possibility, one soon realizes that Durkheim's theory of religion has emerged from the dialectic process involving the inscription of his ideas in a particular type of material support (paper), first with the aim of having them delivered as lectures, then of having them published in print as a book. Contrary to Alexander's grand voluntaristic synthesis, however, the empirical reconstruction of Durkheim's theorizing that was to be materialized in Elementary Forms shows little sign of such an overriding concern on the part of Durkheim while researching and helping with the composition of the book.

\section{Writing Les formes élémentaires}

In this section and the next, we contrast Alexander's synthetic narrative of Durkheim's intellectual development with a narrative that takes the materiality of Durkheim's theorizing seriously. This alternative account is a collaborative endeavor, combining some of the most recent historically minded scholarship on Durkheim's writing process of Les formes élémentaires de la vie religieuse. Le système totémique en Australie (e.g. Jones 2001; Miller 2012) with our own archival research on its translation and reception in the English-speaking world. By tracing the evolution of the successive drafts of Durkheim's work, we will show how Durkheim's theorizing unfolded out of the dialectic between form and content. Such textual comparison allows us to appreciate the exceptional moment of intellectual creativity on the part of Durkheim. By locating this 
moment in the four-year period between 1908 and 1912 it questions Alexander's central thesis about Durkheim's mid-1890s shift toward subjectivity, as well as his subsidiary claim that “in its essentials, Durkheim's sociology of religion never changed after 1898.” (Alexander 1982: 238) On the contrary, Durkheim's theorizing on religion evolved until the last draft of the work in 1912, as he taught on the subject, corresponded with his associates, and worked on the book's draft. This suggests, we contend, that theorizing cannot be understood apart from the specific materiality constituted by the social institutions, groups, and documentation within which the practice of thinking takes place.

There is no doubt that Durkheim is the author of Formes. Yet it would be wrong to infer from this that Formes is the work of a solitary genius. In fact, of all the sociological classics Durkheim's oeuvre was most thoroughly a collective production (Collins 2005: 101; see also Besnard 1979, 1983; Fournier 2014). In no other book is this clearer than in Formes. Formes is, to a large extent, the product of the Durkheimian movement in the sense that this was a collaboration oriented towards the development of a theoretical approach and an empirical program of research of social and religious phenomena. A key institutional platform of the Durkheimian movement was L'Année Sociologique. This new journal provided Durkheim and his associates with an outlet where to publish programmatic statements and major pieces of research, including the essay "De la definition des phénomènes religieux [Concerning the Definition of Religious Phenomena]" (1899) on his core theory of religion with which Durkheim launched the journal. As soon as Durkheim's theory begins to circulate in the pages of L'Année, however, news of a path-breaking ethnographic study of totemism in Australia reach Paris, seriously shaking the Durkheimians program of sociology to the core. In the following decade, the Durkheimians's answer to the challenge set by Baldwin Spencer's 
and Francis Gillen's The Native Tribes of Central Australia (1899) will take many forms but none as definite and encompassing as Formes.

Behind the print publication of Formes in 1912, there lies a five year research period culminating in the draft of the eventual work, a lecture-course on religion and its origins in 1906, and another five years to produce a final manuscript, essentially complete in 1911 and with the publisher early in the following year. To begin with, it is largely consensual that Durkheim's treatment of religion throughout the 1880s and early 1890s was "largely formal and simpliste." (Lukes 1973: 240) What is less clear is when and why Durkheim's theorizing began shifting toward the formulation that will be eventually inscribed in the pages of Formes. As we have seen above, Alexander's argument is that the shift in Durkheim's treatment of religion is but a consequence of a more general, previous change in his sociology, a shift Alexander locates in a series of publications between 1893 and 1894 where Durkheim is said to begin operating with a more voluntaristic model of association. From this perspective, Formes is but the last and most articulated expression of a position long held by Durkheim.

Yet if one conceives of Formes as the material expression of Durkheim's theorizing and reconstructs the steps leading to its print publication in 1912, the sequence of events that emerges is markedly different. Consider the successive beginnings attributed to Durkheim's crucial “new" understanding of religion. Some authors, such as Alexander, point to the 1899 essay "Concerning the Definition of Religious Phenomena,” others, to the 1902 essay on totemism (e.g. Jones 2001: 48); others still to the 1906/1907 lecture-course on religion (Miller 2012). In fact, we think, all these documents constitute successive steps in the development of Durkheim's thinking, each featuring significant advances toward the definite formulation of his ideas in Formes. Common to these writings, Formes included, is the ethnographic 
evidence provided by Spencer and Gillen's The Native Tribes of Central Australia; what changes is Durkheim's way of making sense of this material vis-à-vis competing approaches.

While it is undeniable that the 1899 essay inaugurates a new way of thinking about ancient religion, it is also still riddled in contradictions. As Durkheim will later concede in Formes, one such contradiction was to simultaneously posit the universal character of the dualism of the sacred and the profane while conceptualizing the sacred as an energy able to spread everywhere and permeate everything, thus leaving nothing profane. No less important, in this essay the theory it outlines is still insufficiently voluntaristic, to adopt Alexander's vocabulary. In fact, Durkheim's model here follows James Frazer's largely rationalist and utilitarian conception of taboo in Totemism (1887). As a result, religious beliefs are here defined solely in terms of their obligatory character, as Durkheim would later lament in a footnote in Forms (1995: 44, n. 68). In his essay on totemism, Durkheim (1902) expands his understanding of the nature of religious beliefs. This shift in analysis is a reaction to Frazer's and Baldwin Spencer's utilitarian interpretation of the Intichiuma, a ritual practice of an Australian aborigine people called the Arunta. Frazer and Spencer read this Arunta ritual as a completely rational system of cooperative magic, arguing that the function of totemism was economic. Durkheim finds in Robertson Smith's earlier theory of totemism (1889), which emphasized both the joyous nature of the earliest religious rituals and the social integrative function of such rituals, the key that allows him to supersede Frazer's and Spencer's utilitarian interpretation. In particular, as Robert Alun Jones suggests (2001: 51-2), this allows Durkheim to shift his analysis from the negative aspects of the cult such as taboos and interdictions, to the more positive practices such as feasts and communal sacrifices, hence taking a significant step toward his mature understanding 
that the obligatory character of religious beliefs arises from the fact that they belong to the group that enforces them on its members. But it is not until his lecture-course of 1906/1907 that Durkheim realizes that stating that religion and society were originally fused together in totemism, like he did in his 1902 essay, is a mistake. In the beginning, these two aspects were separate. This suggests that the entanglement between sacred and profane is a historical development, and that one should be able to disentangle them analytically. As Watts Miller stresses (2012: 235), this is what Durkheim sets out to do in this lecture-course as he makes two important theoretical breakthroughs: the novel understanding of the idea of "effervescence" " together with the idea that the sacred and the profane operate in two different times. In the previous year, Durkheim described the French Revolution as a "creative era" during which the "effervescence and collective enthusiasm" took on a "religious character." (1905: 382) Around the same time, other Durkheimians can be seen tackling the problem of how exceptional events such as the French Revolution and routine moments are related. Henri Hubert, in an essay on the collective representation of time, explored the nature and structure of calendars (1905). This was also a concern of Durkheim's nephew, Marcel Mauss, in an essay on the seasonal variations among the Eskimo (1906). Partly due to this collaborative work, Durkheim expands his conception of effervescence. No longer limited to exceptional periods, effervescence is now conceived of as occurring also in normal times as exceptional events become embedded in collective memory through recall in rites of a calendar's periodic times. This idea of the two times of the sacred and the profane appears prominently in the lecture-course on religion, where Durkheim applies it to Australia within a further revised version of his theory.

As a result of these successive modifications to his thinking, Durkheim is now in a position to resolve the contradiction in which he incurred in the 1899 essay and to 
articulate a more fully voluntaristic, non-utilitarian theory of religion. The idea of a double temporality regarding the dualism between sacred and profane allows Durkheim to solve the paradox in which he had incurred earlier: the source of the sacred's energy in exceptional effervescent times while erecting barriers to its spread everywhere in routine times. But also and not least, the idea is a way of tackling the external problem posed by Spencer and Gillen's ethnography in Australia. It makes possible to concede that the totemic group might lack importance in ordinary times yet also to assert that it remains the centre of socio-religious life thanks to its pre-eminent role in the great communal rites, social renewal and effervescence of special times (Miller 2012: 239). This is, in brief, the immediate intellectual context which frames Durkheim's writing of his last major monograph.

Durkheim begins writing the draft of the final text in the spring of $1908 .^{8}$ In writing up this draft, Durkheim kept to the same basic plan he had laid down in his lecture-course of 1906/1907. This constitutes a draft of the final text and, after an introduction, goes over in outline the material of what became Book I, Book II and Book III's two opening chapters on a negative cult and on sacrifice as a rite of the positive cult. The draft includes a brief conclusion on what makes religion "eternal" (Durkheim 1907: 122). The final text arrives at the desk of the editor, Félix Alcan, on February 7th 1912, as certified by the contract signed by Durkheim in that date at 108 of boulevard Saint-Germain. Durkheim receives the final proofs of the manuscript "around May 20." "The work, entitled Les formes élémentaires de la vie religieuse. Le système totémique en Australie, is published in June 1912 (Borlandi 2012: 284). In these four years, Durkheim will draw upon, expand and revise his 1906/1907 lecture-course in order to produce a manuscript that is, in several key respects, profoundly different from the original draft. 
Drawing upon Watts Miller's meticulous inter-textual analysis (2012: 235-40), let us now discuss the changes made by Durkheim. Some of these changes involved adding new material, others interweaving existing passages in new contexts, and others still the removal of certain segments of the text. Uniting this composition was Durkheim's attempt at making sense of religion in a thoroughly sociological fashion. His theorizing on religion is a decade-long process involving regular oral and written communication with other members of the Durkheimian group, the preparation and deliver of lectures on the topic, and individual reflection involving consulting a vast set of documentation and writing up a draft intended for publication as a book. The changes Durkheim makes to the final draft in late 1911, early 1912 are but the last step of this process: they offer precious textual evidence of the way Durkheim's theorizing kept evolving until the very last moment before submitting the manuscript to the editor.

The first type of change involves expanding his earlier account. In Book III, after the analysis of sacrifice, Durkheim adds several new passages on rites. He also expands the overall conclusion to the work. Theoretically, this results in a new concept of rite as a fundamentally social phenomenon. This new concept is absent from the draft. Let us see how Durkheim got to this new understanding. He begins by transferring a seemingly unimportant remark about two different aspects of a rite from the end of the draft to the new chapter that follows: "The profound moral efficacy of the rite determines belief in its physical efficacy, which is illusory." (1907: 122) Once relocated, this statement functions in an entirely different way. The physical act of reinscribing this statement in a different position in the economy of the text reflects a sudden expansion of Durkheim's reasoning regarding what is entailed by a rite: it now provides Durkheim with the conceptual basis upon which to distinguish different kinds of rite. Concretely, Durkheim uses it to characterize one particular type of rite, which he 
designates as mimetic rite: "The moral efficacy of the rite, which is real, has driven belief in its physical efficacy, which is imaginary." (1976: 359) This type is then contrasted with the dramatic rite, to which Durkheim attributes a crucial significance. Dramatic rites, also known as representative or commemorative rites, are of exceptional importance as they require no belief whatsoever in their physical, material efficacy. In the eyes of the believer, they function in a purely representative way: their efficacy is purely social or moral. This crucial advance in Durkheim's theorization of religion as a fundamentally social affair is the product of his writing up the final manuscript of Formes. It is absent from the draft, and only appears in the work. In between, there was Durkheim's sensuous involvement with the text, through which his understanding kept evolving in significant ways.

A second type of intervention by Durkheim in the text brings us back to the etymology of the word "text" (from the Latin textus, a tissue, which is in turn derived from texere, to weave) and its textile imagery. By comparing the draft with the work, one can see Durkheim weaving together different segments of text on the elementary forms of thought along the whole body of the work, where he applies these highly abstract neo-Kantian philosophical categories to specific aspects of religious experience. ${ }^{10}$ Crucially, Durkheim's sensuous interweaving of statements across the manuscript happens exactly when he decides to provide a sociological answer to the philosophical question of the nature of knowledge, the most abstract and ambitious purpose of Formes. A fuller appreciation of Durkheim's textual interweaving while composing Formes, however, requires us to go beyond the inter-textual context of the draft and the work to consider the earlier 1903 essay "Primitive Classification" (Durkheim and Mauss 1903). ${ }^{11}$ Between this essay and the draft, Durkheim introduces the new idea that the origin of logical and conceptual thought lies in the creative energy 
of effervescent times. Yet it is between the draft and the work that Durkheim makes the most significant changes. Both in the centerpiece of the draft and of the work, Durkheim discusses the idea of an elementary "force, "energy" or "power." How this elementary category manifests itself is then interwoven into chapters 3 through 5 on rites in Book III. Durkheim considers successively three categories of the understanding: time (which Kant had described as a "form of intuition"), causality, and creativity. As to the problem of time, Durkheim's sociological answer begins by noting that social life does not proceed in a linear, constant pace. Rather, in any given community, there are markedly different rhythms with periodic upsurges of energy. Durkheim finds the solution to account for this apparent contradiction in rites. Rites, he explains, offer an experiential space in which this elementary energy or force is renewed periodically. Next Durkheim discusses causality. He offers a description of social life that works according to an underlying logic. Again, he resorts to the idea of an elementary energy to describe the nature of the forces at work in the necessary connections between the different elements of social experience. Finally, Durkheim considers creativity. This turns out to be of crucial importance for Durkheim's argument as a whole. Social change, both in its sacred and profane dimensions, proceeds by means of a constant process of re-creation of its basic structures and institutions through effervescent energies.

All of these different types of changes show Durkheim's thinking changing significantly as it is successively inscribed in the essay, in the draft, and eventually in the work. With each re-inscription of Durkheim's thought, there comes a set of changes to Durkheim's thought itself. Instead of a single, overarching "shift toward subjectivity" in the mid-1890s what our analysis shows is that a number of crucial developments, including the one identified by Alexander, occur as Durkheim's theorizing is put into 
writing for different purposes, but most importantly for the publication of Formes. Rather than a plea for intentionalism, or a retreat toward contextualism, we believe there is much to be gained from a greater appreciation of how thinking often operates in sensuous ways. The sensuousness of the late Durkheim's theorizing is at its peak when it is most abstract. For Durkheim, thinking about ways of rendering Kant's epistemology amenable to sociological analysis was not only an intellectual challenge: it was also a creative, deeply tactile process. More generally, it is apparent that the writing up of Formes and its subsidiary materials for almost a decade was the way through which he was able to position himself in some of the intellectual debates of the time, contribute to the early institutionalization of sociology in French academia, achieve greater clarity about his means and purposes, and eventually articulate one of the most potent anti-utilitarian theories of the twentieth century.

On February 7 1912, the final version of the work arrives at the desk of the editor, Félix Alcan, and the book is published in June under the title Les Formes élémentaires de la vie religieuse. Le Système totémique en Australie, with 647 pages and a folded ethnographic map of Australia in the end of the book. ${ }^{12}$ With the publication of the work in its definite form (at least, the first and last edition published during Durkheim's lifetime), one could be led to think that through this particular inscription Durkheim's theory would achieve a fixed, stable status requiring from the interpreter only a set of hermeneutic skills to make sense of text. The truth is that the print publication of Formes in 1912 is but the first of a long line of inscriptions of the late Durkheim's ideas on religion and epistemology. These ideas will be periodically reinscribed, sometimes in translation, over the next century. With each re-inscription, changes will be made to the typographic form through which those ideas will be presented to the reader, translation choices will be exercised as to the best way of 
rendering Durkheim's text in French into foreign languages, paratexts will be written as to frame the scope of hermeneutic possibilities in approaching the work, and critical commentary will be produced intent on exploring the implications of those ideas.

\section{From Les Formes to Elementary Forms of the Religious Life}

Commentary over the meaning of the late Durkheim in the social sciences and in the humanities throughout the twentieth century has always returned to the book, either in materialistic terms (as in commentary that reduces meaning to the external factors of its production) or in idealistic terms (where meaning is assumed to exist independently of the material conditions for its existence). Alexander's critical commentary of Formes, despite its attempt at reconciling detailed textual exegesis with close attention to contextual factors, falls closer to the second pole. Few, however, seem to have considered the possibility that the meaning of the book - and of its author - could have emerged from the dialectic between content and form. This is what partly explains Alexander's genealogy of influence of Formes during the twentieth century, which locates the meaning of the work within a grand theoretical synthesis toward subjectivity. By following the book, however, one can produce a different kind of genealogy. Such a genealogy, rather than reaffirming one self-legitimizing interpretation, is explicitly aimed at unearthing as many interpretations as possible. We begin by briefly recounting the creation of the first translation of the book into English; next we address the reception of the work in postwar American social sciences, a period when critical commentary on Elementary Forms took many narrative forms, from Parsons's and Alexander's synthetic narratives to positivist, contextual, or humanistic ones. Our 
primary aim in what follows is to discuss this plurality of narrative forms in the reception of Elementary Forms.

Shortly after its publication in French, there are plans to have Formes translated into English. The translation originates in the interest on the part of Durkheim to have its work circulated among an international audience and the persistent efforts by Joseph Ward Swain, a young American student of his who will act as a literary agent of sorts and translator. The circumstance that Swain, an Episcopalian from South Dakota, will have to reconcile the work of translation with his own doctoral research, ${ }^{13}$ will not benefit the quality of the translation. Yet if it were not for Swain's efforts, not only actively seeking out alternative publishers when the original ones abandon the project, but also conducting much of the negotiations with the publishers, the whole project would have probably floundered.

The correspondence exchanged between Joseph Swain, on behalf of Durkheim, and Cecil A. Reynolds, managing director of the publishing house George Allen and Unwin, in Oxford, offers valuable evidence as to the sequence of events surrounding this editorial project. ${ }^{14}$ Durkheim and Swain's first choice, however, was not Allen and Unwin but an American publisher, Macmillan, in New York. Macmillan, however, turned down the project. Their reply was that Formes was "a work which could be published in England to much better advantage than in the United States" 15 and it is them who recommend Allen and Unwin as an alternative, noting they are "the publishers of an important series in Philosophy and Religion" and "perhaps in as good a position as any publisher to handle this book." Durkheim's original plan of addressing an American audience is thwarted, but Swain was not to be dissuaded that easily. Following the American's editor advice, he approaches Allen and Unwin in October 1914. Swain begins by informing them that he has been studying with Durkheim in 
Paris during the past year, that Durkheim gave his permission to translate the book, and that he had already completed a first draft translation of a portion of it. Before going any further, however, Swain wanted to see whether some sort of an arrangement in regard to its publication could not be made in advance. As to persuade Allen and Unwin, Swain takes the initiative to briefly present the character and scope of the book to be translated, along with the draft of his translation of the introduction, the conclusion and the table of contents. This, he assures the editor, will be sufficient to show that the book:

(...) is in no way a highly technical treatise on the phenomena of primitive religions, but is rather an attempted interpretation of them. While [f.2] it is true that a certain amount of space is necessarily devoted to the description of these phenomena, this is not at all the primary purpose of the work. As is clearly set forth in the pages I am sending you, M. Durkheim's object is to study these religions in order to seek in a scientific manner the origin and nature of religion in general. The book, then, is an exposition of his thought in regard to what he calls «Sociologie Religieuse» and the summing up of the work, not only of M. Durkheim himself, but also the entire school of French sociologists who have been publishing «L'Année Sociologique» for the past 15 years. In fact, this book will undoubtedly long remain the classic exposition of this sociological theory of religion. In France this sociological thought of M. Durkheim is recognized as one of the two most important currents of contemporary thought, the other current being that developed by M. Bergson. From my own experience at the Sorbonne, I am able to state that the work of Durkheim there is regarded as equally important with that of Bergson. So knowing the success of English translations of Bergson's writings, it has seemed to me that there is a need for a translation of Durkheim as well. ${ }^{16}$

Reynolds replies the next day, showing interest in the project and asking for more details. Swain retorts, explaining the portion of the translation he had sent them was not he had done but that he had not completed the translation as yet. At present, Swain explains, he has translated about one-half of the book and offers to send Allen and Unwin the rest of what he has translated to date. This he does on October 26, with the following accompanying note: 
I am sending you under another cover another chapter of my translation of Professor Durkheim's book, “The Elementary Forms of Religious Belief." As I have already explained to you, I consider this chapter one of the most important in the book, so it has seemed to me that it will aid your Reader greatly in forming an opinion of the book. Also, since it is written in a somewhat different style from the chapters I have already sent you, where considerable space was necessarily given to a technical description of the phenomena of the Australian religion, it will aid in showing that the book is not a mere technical treatise, but rather an attempted explanation of these elementary phenomena. I have as yet received no reply from the Felix Alcan Company in Paris, but as soon as I do, I will let you know what they say.

Yours very truly,

J.W. Swain [pencil addition: M.A. Harvard, B.A. Columbia]

This is important for several reasons. First, it shows that the title of the work in translation was still undecided. Second, it introduces the figure of an external reader who will play an important yet critical role in the translation process. Third, it shows the continuing efforts by Swain to persuade Allen and Unwin of the potentially wide appeal of the work.

Between November 1914 and March 1915, there is a voluminous amount of correspondence between Swain and the publisher. First, the reader is consulted to give his opinion of the quality of the translation meanwhile undertaken. He will note that there are "various solecisms" but that these are "trivial matters" which can be easily adjusted when the translation is completed. Reassured with this answer, Swain proceeds and concludes the translation sometime in late 1914. Durkheim reads the translation in early 1915 and seems very satisfied with it, as he tells Swain that: "any changes he might want to make would be so slight that they could easily be marked in the proofs." $" 17$ On February 4, 1915 Swain sends Allen and Unwin his translation. As it transpires, Durkheim was intent on reversing the original order of the title and subtitle in French. Maybe because he thought Elementary Forms would not be an appealing title to the 
Anglo-American public, Durkheim's first choice was Totemism. ${ }^{18}$ As it turns out, however, Durkheim's title of choice was not to be. This is because of the intervention of the reader hired by Allen and Unwin, John Henry Muirhead. A well-known British philosopher at the time whose main interests revolved around religion and morals (e.g. 1892), Muirhead notes that "Totemism" might lead to a confusion with James Frazer's book with the same title, and that it would be preferable to retain the literal translation of the French title: "The Elementary Forms of the Religious Life." And this is how the English translation of the work was to be christened.

If Muirhead's suggestion avoids an unfortunate confusion with Frazer's book, it does little to prevent Swain's own unfortunate translation choices. ${ }^{19}$ Very much as the correct translation of c'est la vie! is not that's the life!, but that's life!, the title of Durkheim's major work should have not have been translated, even if literalness was to guide it, as The Elementary Forms of the Religious Life, but as The Elementary Forms of Religious Life. Swain's quest for literalness will have important implications for how the work is rendered into English, starting with the title but which extend well beyond it. In the turn of the century, literalness was thought equivalent to accuracy, and readers were expected to hear not only foreign words but foreign structures "through" their own language: for instance, to read an English-American translation of the Bible was partly seen as an exercise of the readers' Greek syntax (Glassman 1981: 48). Likewise, Swain's translation of Elementary Forms made generations of English-speaking readers to exercise their French syntax and even vocabulary, as Swain populated the text with false cognates (Fields 2005: 160-5).

Printed in Plymouth in the printing presses of William Brendon \& Son, the English translation of Durkheim's The Elementary Forms of the Religious Life is said to be 'just out' in the Review of politics, literature, science and art of October 16, 1915 
(vol. 120, n. 3129: 381). Sold at 15 shillings, its first print-run is of 1,000 copies, 250 of which are to be exported to the United States where the book will be distributed by Macmillan. For eighty years this will be the entry point for thousands of Englishspeaking students to the work of the late Durkheim - or, better still, to the last work of Durkheim as the "late Durkheim" was still years to come.

The periodization of Durkheim's writings, his canonization in sociology and anthropology, and the relationship between his contributions and those of other classics, will be the object of much dispute among commentators during the post-war period. It is not unlikely that Swain's quest for literalness have had some impact in the reception of Durkheim's last work in the Anglo-American context. The sheer variety of interpretations, however, seems to suggest that this did not determine per se the reception of Elementary Forms. Rather, the hermeneutical encounters between the work and commentators, who as a rule read French and most probably have consulted both the original and the translated versions of the work, seem to have been shaped by a much wider set of factors, including personal research interests, disciplinary affiliations, national traditions, and broader ideological and epistemological orientations. As these multiple factors influence each other and interact with contextual circumstances, specific narrative forms of the sociological tradition seem to emerge (Levine 1995; for an assessment, see Camic and Joas 2003). ${ }^{20}$ Such narrative forms can be seen in operation in the case of the critical commentary of Elementary Forms in this period. As a result, vastly different and mutually incompatible interpretations of the work emerge: in particular, each vision of the sociological tradition brings with it a distinct Elementary Forms.

From a contextualist perspective, Elementary Forms is a product of bourgeois ideology, offering an instrumentalist picture of social order. Contextualist 
interpretations are distinctive in that they subordinate the cognitive dimension of the work to other kinds of orientations (e.g. ideological, religious or socio-economic). Changes in Durkheim's orientation are then attributed to reasons exogenous to the theory and research of sociology. In the case of the 1960s American academia, contextualism was often associated with neo-Marxist views. A case in point is Alvin Gouldner's "structural" reading of Durkheim. In the Introduction to Socialism and Saint-Simon, Gouldner sees Durkheim “converging” with the materialism of Marx as Durkheim rejects the theological explanation of values as "divinely given and thus without a developmental history" (Durkheim 1958: 24) and predicates the existence of social values upon the interaction between concrete persons. But Durkheim's theoretical convergence with Marx should not be taken as a sign of ideological convergence. On the contrary, Gouldner portraits Durkheim as the quintessential conservative defender of bourgeois class interests against the working class movement of his time (see also Gouldner 1970: 119). Elementary Forms thus becomes an expression of Durkheim's class interests. In the 1960s, Gouldner was hardly alone in his contextualist approach to Durkheim. Before Gouldner, Irving Zeitlin and Peter M. Blau offered similar "structural" readings: the former saw in Durkheim expressions of "a conservative and authoritarian ideology that dominated his entire sociological system," Elementary Forms included (1968: 241), while the latter found in Durkheim's structuralism, and in particular his emphasis on concrete group pressures, an alternative to Parsons's structural-functional emphasis on the structuring effect of values through internalization (1960).

If one adopts a positivist perspective, Elementary Forms becomes a repository of scientific outputs. Positivist accounts typically assume the form of an optimistic narrative about the accumulation of knowledge. Progress is made as we move from 
insufficient or uncertain knowledge toward more robust, certain science. From this perspective, interpreting Elementary Forms becomes an exercise in mining it for contributions to the progress of the discipline. The earliest example of such a positivist narrative of the sociological tradition that mentions Elementary Forms is Park and Burgess's Introduction to the Science of Sociology (1921: 35; 193-6). For Park and Burgess, the main contribution of the work came in the form of the concept of "collective representation:" they adapt a portion of the conclusion where Durkheim discusses logical thought to create a section on "Collective Representations and Intellectual Life." This will be the first segment of Elementary Forms to figure in a sociology textbook in America, indeed of any of Durkheim's works, and it is framed as an exemplar of a "social realist" position (one of the earlier sociological schools "scientific" sociology was meant to replace). A decade later, in Emile Durkheim and his Sociology, Harry Alpert recuperates the realist vs. nominalist framework as to assess Durkheim's contributions. For Alpert, Elementary Forms is but the last expression of Durkheim's life-long attempt at superseding the nominalist-realist divide, and, as such, as the most elaborate contribution to that end one can find in his oeuvre (1939: 160-3). Despite its contributions to the sociology of knowledge (1939: 55), Elementary Forms is narrowly classified as one of Durkheim's writings on "religious sociology" (1939: 49).

From a pluralist perspective, Elementary Forms is an exemplar of a theoretical approach or school of thought. Pluralist narratives see the history of sociology as the sum of multiple independent theoretical approaches, neither converging nor progressing towards a future single position or paradigm. While some commentators emphasize the role of dialogue in the development of these multiple strands (Levine 1995), others see the differences separating these traditions as unsurmountable. The archetypal example 
of the latter kind of pluralism is Pitirim Sorokin's Contemporary Sociological Theories (1928). In here, Sorokin depicts Elementary Forms as a representative work of the "sociologistic" school of thought. His evaluation of the work is mixed at best. Sorokin praises Durkheim's sociologistic explanation of religious symbols and conceptual knowledge, but criticizes the underlying conception of an exterior collective mind as one-sided and reductionist (1928: 466). ${ }^{21}$ Following Sorokin's interpretation, but replacing “sociologism” with “organicism,” Don Martindale discusses Elementary Forms as a work representative of the "organismic" sociological tradition. Unlike Sorokin, however, Martindale is sensitive to the development of Durkheim's thought. Since "during the course of his development, Durkheim's underlying organicism grew ever more pronounced" (1981: 89) Elementary Forms is presented as the most articulate expression of Durkheim's organicism. Concretely, Martindale locates it in a new and distinct phase of Durkheim's work that had begun in 1898, a phase characterized by a "more idealistic conception of the social group, with more emphasis on "collective representations' and 'by adventurous speculation concerning the social origin of morals, values, religion, and knowledge.” (Benoit-Smullyan cited in Martindale, 1981: 89)

From a humanist perspective, Elementary Forms comprises a valuable moral lesson. Humanist narratives distinguish themselves for equating the history of sociology with a sociological canon of classic texts. Such a corpus of classic works is presumed to contain intellectual and moral achievements that present-day readers cannot ignore at the risk of moral impoverishment. Robert Nisbet's The Sociological Tradition (1966) and Raymond Aron's Main Currents in Sociological Thought (1965-67) offer two good illustrations of accounts of the history of sociological ideas in this vein (see also Coser 1971: 139ff.). Nisbet analyses the classic works of the sociological tradition in search of the "unit-ideas" contained in them. The careful study of sociology's unit-ideas promises 
to unveil the discipline's most valuable and enduring statements. It is under the unitidea of "community" that Nisbet considers Elementary Forms (1966: 86). He not only rejects any fundamental difference between the early and the late Durkheim, as he emphasizes that what Elementary Forms shares with all of other writings by Durkheim - including the books posthumously published and the articles that appeared in L'Année - is a "social metaphysic" that is apparent since his first writings and "a methodology rooted in the conviction that (...) all human behavior above the level of the strictly physiological must be regarded as either emanating from, or else sharply conditioned by, society: that is," Nisbet details, "by the totality of groups, norms, and institutions within which every individual human being consciously and unconsciously exists from the moment of his birth." (1966: 86-87) Likewise, Aron discerns no discontinuity in the work of Durkheim. Instead, all of his writings offer variations on the same central humanist plea for rationalist individualism. For Aron, however, Durkheim's emphasis on the collective was at times done at the expense of the individual, both epistemologically and politically. The most glaring example of this was Elementary Forms, which Aron's liberal-conservative persuasion (and the place it afforded religion in regulating democratic passions) found profoundly unappealing. Hence Aron's incensed humanist indictment: "It seems to me absolutely inconceivable to define the essence of religion in terms of the worship which the individual pledges to the group" for this would "inspire in men a fanatical devotion to partial groups, to pledge each man's devotion to a collectivity and, by the same token, his hostility to other collectivities." Aron then concludes: "To suggest that the object of the religious feeling is society transfigured is not to save but to degrade the human reality which sociology seeks to understand." (1967: 66) 
From a synthetic perspective, Elementary Forms is a stage in the development of Durkheim's ideas. Narrative accounts of the history of social thought in this genre tend to employ painstaking textual exegesis in order to detect implicit processes of theoretical convergence between a number of authors. In so doing theoretical syntheses promote a reorganization of the theoretical landscape of a discipline, from an earlier stage marked by conflict between partially correct approaches to a future stage characterized by theoretical consensus around a new paradigm or research program. The first synthesis figuring Elementary Forms is Talcott Parsons's Structure of Social Action, where it represents the culmination of Durkheim's theoretical convergence with Weber while transitioning from an early positivist emphasis on adaptation to a mature voluntarist position where he considers normative factors as well (1937: 343ff.). Around the same time Alexander publishes Theoretical Logic, ${ }^{22}$ Jürgen Habermas publishes The Theory of Communicative Action (1984-87). Despite the significant differences separating these three narratives, Elementary Forms performs the same role in all three: Parsons first, then Alexander and Habermas, all construe this book as a sort of antiutilitarian icon, signaling a key developmental stage in Durkheim's thought away from positivism toward subjectivity (Alexander) or intersubjectivity (Habermas). Indeed, Elementary Forms occupies a key position in the "paradigm change" (1984: 399) in which Habermas is interested: the linguistic turn in the social sciences of the 1970s and 1980s. He considers Durkheim's theory of religion in order to complete the program of reconstruction of "symbolically mediated interaction and action in social roles" (1984: 43) pursued by Mead. Mead's explanation, however, only holds for ontogenesis. ${ }^{23}$ If one wishes an explanation for the phylogenetic transition from symbolically mediated to normatively guided interactions, one needs to turn to Elementary Forms. In the footsteps of Parsons's “voluntaristic" reading of Durkheim, Habermas too sees an early 
Durkheim, still tied to the "tradition of the philosophy of consciousness," who provides a ultimately circular explanation of the origins of the sacred and thereby the meaning of moral authority: "The moral is traced back to the sacred, and the sacred to collective representation of an entity that it is itself supposed to consist of system of binding norms.” (1984: 50) The way out of this conundrum involves a paradigmatic change on the part of Durkheim, away from the paradigm of consciousness towards intersubjectivity. Nowhere is this paradigmatic change clearer than in Elementary Forms. This crucial work opens up a path for Durkheim that "point in the end to a clarification of the symbolic structure of the sacred and to a non-positivistic interpretation of collective consciousness." (1984: 51)

Either a product of bourgeois ideology, a repository of scientific outputs concerning collective representations, an exemplar of sociologism, a classic statement on community, or the key developmental stage in Durkheim's thinking away from positivism, the politics of the book has originated fundamentally different visions of the work. In fact, over the years Elementary Forms has been construed by commentators in various and mutually contradictory ways. All these commentators have one thing in common, though. They have all taken the book for granted. Primarily interested in the ideas inscribed in its pages, commentators were far more likely to pay attention to Durkheim's intentions, biographical circumstances, career interests, and broader contextual factors such as ideology, intellectual traditions, academic disciplines or socio-economic conditions than to the dialectic between form and content as a source of meaning. As a result, none of these narrative accounts examines Elementary Forms as we have proposed here: the material expression of Durkheim's theorizing on religion and epistemology. Advantages of this reading, we posit, include respecting the discourse actually exercised by Durkheim (as opposed to forcing our picture of 
Durkheim into a framework set by our parameters), not glossing over Durkheim's concern with individuality (as in the role of individual agents in processes of re-creation of society's basic structures and institutions through effervescent energies), nor his theoretical and methodological advances, while trying to pay attention to the substantive arguments made by Durkheim. This, of course, besides offering a more rigorous understanding of how theorizing often unfolds in a dialectic relationship with some kind of material support in which ideas are inscribed. This contribution also provides us with a valuable vantage point from which to assess critical commentary on Elementary Forms today.

\section{Elementary Forms today}

Commentary on Elementary Forms today no longer refers to Swain's 1915 translation. In the 1990s and early 2000s appeared two new editions and translations of Durkheim's last work, rapidly establishing themselves as the authoritative entry point to the work in English-speaking countries: the 1995 Karen Fields translation (Free Press) and Carol Cosman's 2001 abridged translation for Oxford University Press. These two new editions have gradually come to function as outlets or platforms through which interpreters were able to advance claims regarding the relative importance of Elementary Forms (and Durkheim) for various ends. Jeffrey C. Alexander, who has established the cultural sociology program around it, by and large spearheads critical commentary on the work today. Both the new translations and Alexander's commentary, however, were made possible by the developments in Durkheimian scholarship discussed above, but also by broad intellectual movements and new 
disciplinary orientations. Whether they are able to critically reflect upon this, or merely reproduce it (thus imposing it on the work), is something we will discuss next. In any case, the fact remains that, taken together, these developments in the reception and edition of the work mark a new phase in the social life of Elementary Forms.

By and large, the reception of Elementary Forms in America has been anything but a success story. In the 1950s and 1960s, the general view of the work was that it had become a marginal work and an overlooked text (Morrison 2003: 399). Even the paperback reprint of the work in 1965 did not seem to have much difference, at least in sociology. Since between the late 1960s and the early 1980s sociologists, especially critical sociologists, were predominantly operating with anti-normative modes of theorizing, Elementary Forms remained out of sight. There were those, of course, who did pay attention to the work, such as Robert Alun Jones, Edward Tiryakian, Robert Bellah and Edward Shils. These figures may have been important in American sociology at the time, but for the most part they also remained isolated thinkers without any significant mass basis of support. While for many anthropologists, Elementary Forms constituted a key foundational text, it is only in the early 1990s that its canonisation in sociology gathers pace. (Smith and Alexander 1996: 587) ${ }^{24}$

Key to this was the advent of the "new Durkheim studies" of the 1970s (e.g. Clark 1968, 1973; Lukes 1973; Filloux 1977; Jones 1977; Birnbaum 1976). Crucial in this regard was the new journal Etudes Durkheimiennes, created in 1977 under the tutelage of Philippe Besnard. In 1972, Steven Lukes publishes the magisterial Emile Durkheim: His Life and Work. Lukes' path-breaking intellectual biography emerged from extensive empirical historical research (including interviews with many of Durkheim's relatives, archival research and unpublished sources, namely letters and manuscripts) and from a "new" understanding of Durkheim's work as a whole. Lukes' 
study opened the way to a new generation of Durkheimian scholars who revolutionized our understanding of the French master's collaborative network, institutional mode of operation, and his internal intellectual development. The subsequent opening up of archives also provided new data about Durkheim's life and work, and the opportunity for new analyses of the work he produced during the complicated intellectual and social conditions surrounding the emergence of sociology in France. As a result, since the 1970s, Durkheimian studies have been steadily increasing, around figures such as, besides Lukes himself, Marcel Fournier, Philippe Besnard, Robert Alun Jones, Massimo Borlandi, and W.S.F. Pickering.

In addition, the rise of broad intellectual movements such as post-structuralism, post-modernism and cultural studies between the 1970s and the 1990s signaled the exhaustion of modernist ways of thinking and a general swing in the social sciences and humanities toward hermeneutics, semiotics and cultural analysis broadly construed. In this changed intellectual climate, homogeneous and rigid conceptions of society and human agency become increasingly the object of critical scrutiny. A greater concern with the social life of things ensued as an attempt to supersede the modernist chasm opposing materialist and idealist approaches.

The politics of the book were deeply affected by these developments. Their protagonists, which include the editorial agents behind the new 1990s editions of Elementary Forms and commentators, ${ }^{25}$ have drawn upon these developments in their interventions. Consider Karen Fields's 1995 translation of Elementary Forms, the first new translation of the work since Swain's. Fields explicitly positions her work of translation against that of Swain (1995: li-lxi). While Swain's translation is depicted as a modernist representative of the quest for literalness, Fields praises the postmodern hermeneutic license of the translator-interpreter. For Fields, a translation is both a 
product and a process. As a product, it cannot help but appear to be what it cannot possibly be: the text itself, though in a different language ${ }^{26}$ Certainly the writer's craft can foster that appearance whether by giving the author idiomatic language or by making him sound foreign. Whatever the appearance, however, a text cannot move by itself; it must be rebuilt. As a process, then, every translation is a reconstruction, and every translator works like an artisan, not a medium. (Fields 2005: 166) The meaning of the work is dramatically transformed, not only as a result of the changes in context described above, but also as a result of this new rendering of the text into English - a change in both content and form.

It is a change in content insofar as Fields's translation offers a new interpretation of Durkheim. The first sign of this is the title itself. Swain's odd title "The Elementary Forms of the Religious Life" has (finally) been dropped for the correct "The Elementary Forms of Religious Life." More generally, when compared with Swain's, Fields's translation is characterized by its more contemporary use of language as well as her conscious attempt to make her translation reflect (and promote) emerging understandings of the message of Elementary Forms and its place in contemporary sociology. ${ }^{27}$

It is a change in form as the 464-page Free Press edition has little or nothing in common with the previous material incarnations of the work. Crucial in this regard are the paratexts of this edition. The 1995 Elementary Forms has a long, scholarly introduction by Fields herself, in which the reader is introduced not only to issues of language and translation choices, but to the relative contribution of this work to the understanding of Durkheim as a whole. She wants to broaden the readership of the work as to include "American postmodernist theorizers of discursive practices and representations," since it is her view that "dead ancestors should stay dead to us unless 
pleasure and excitement come from getting to know them.” (1995: xxiii) A jazz enthusiast, Fields compares reading Elementary Forms to listening to Wynton Marsalis' "translation" of the "old work" of Duke Ellington. In both cases, the "case for studying old works needs to be made now, partly through the manner of their presentation." (xxiv) Fields's "manner" of presenting Elementary Forms to a new generation, as she notes in the Introduction (1995: xxiii-xxiv), is not simply a matter of recoding words from one grammatical system to another. It involves, she rightly says, recoding texts from one semantic context to another: it involves carrying the letter of the text and the spirit of the original to the linguistic-cultural context of reception. And, we might add, it is also a matter of reassembling material signifiers from one specific typographic form into another. Indeed, the "manner" in which Fields chose to present Elementary Forms for a new generation includes a solid paratextual apparatus. This edition contains hundreds of editorial notes ${ }^{28}$ the ethnographic map of the original French edition, absent from Swain's 1915 edition, which provides the reader with a spatial visualization of the ethnographic materials discussed in the text that clarifies and reinforces their significance, and a comprehensive index, which adds to the sense of scholarly quality of the work as a whole. As a result of these changes in content and form, the Free Press 1995 edition of Elementary Forms marks a watershed in the social life of the book. Closely aligned with postmodernist understandings in the philosophy of translation, and accompanied by a robust scholarly paratextual apparatus, this new incarnation of the work provides material support to the "cultural Durkheim" of the 1990s.

This material support also came in the form of an abridged, student-oriented edition. In 2001, Oxford University Press (OUP) publishes yet another new translation of Elementary Forms. This abridgement, translated by Carol Cosman and covering approximately $75 \%$ of the original text, is commercialized in the Oxford World's 
Classics series, the premier world book series of trade paperbacks in literature and social science. The paratexts of this edition are clear about the intent of positioning the work within the dominant intellectual movements in the social sciences today. In the Introduction, Durkheim scholar Mark S. Cladis, who is responsible for the critical apparatus of this edition, frames the text within his communitarian, culturally sensitive secular lenses (1992, 1999). Invoking Richard Rorty’s pragmatic emphasis on vocabularies, Cladis praises Durkheim for having articulated "a powerful vocabulary for articulating the normative, communal aspects of modern, democratic societies - the vocabulary of religion." Not distant from Alexander's emphasis on public performance and deep cultural scripts, Cladis goes on to argue that one "finds religion wherever public, normative concepts, or rites are employed. Religion, then, pervades traditional and modern - even postmodern - societies." He concludes in an unmistakable voluntaristic, collectivist tone: "The upshot of this, morally and epistemologically, is that human life is, in a significant sense, life together. This is Durkheim's response, and challenge, to a long tradition of Cartesian, individualistic thought." (2001: viii)

Quite independently from these editorial initiatives, Jeffrey Alexander's critical commentary on Durkheim draws upon very much the same interpretive-hermeneutic intellectual movements to pursue a culturalist research program in sociology. The fact that Alexander was not associated with these new translations and editions does not mean, however, that he has been impervious to them. In a book review of Fields's translation for the American Journal of Sociology, Alexander and his associate Philip Smith make the reasons for their endorsement clear (Smith and Alexander 1996). They point to three major factors explaining this emerging centrality of Elementary Forms for mainstream sociology in this period (1996: 587-588). First, there was a broad swing in the discipline as a whole toward cultural analysis. This general intellectual movement 
has seen hermeneutics, semiotics and related interpretive perspectives become more central to contemporary sociological theory. Second, sociologists taking inspiration in Elementary Forms proved able to make use of Durkheim's visionary ideas in the context of a changed intellectual climate. The third reason accounting for the discontinuity in the social life of Elementary Forms refers to the ways in which contemporary scholars have interpreted it: whereas previous readings emphasized objectivist readings, later readings are said to have detected a decisive epistemological break in the middle-period Durkheim. ${ }^{29}$ Smith and Alexander's enthusiastic endorsement of Fields's work of translation is a strong indication of how closely aligned their intellectual interventions around the work are. While Swain's literal, "stilted, convoluted late-Victorian tones" "embody and reinforce the image of Durkheim, the scientist and philosopher," "Fields's reworking of the text gives to Elementary Forms a Geertzian tenor. Here Durkheim becomes the virtuoso interpreter of cultural life, the translator of traditions." Crucially, they assure us, Fields's Durkheim “reads like a daring and imaginative theorist rather than a pedantic relic of $19^{\text {th }}$ century positivism." (1996: 590) Cosmans's abridgement (2001: xxxvi) goes even further in this attempt to bring the text up to date, by retaining all the passages on "topical issues, for example the role of women in religion," while purging the text from "dated controversies" and "the more antiquarian aspects" of Durkheim's thought. A battle between past and present understandings of the work is being waged in the pages of Elementary Forms today, whose victors are to define much of the reception of the text in the coming years.

\section{Conclusion}


Neither an imaginative postmodern theorist nor a pedantic relic of a bygone era, in this chapter we have uncovered a hitherto ignored facet of Durkheim: that of an author committing his ideas to a physical medium, and working them out through it.

Durkheim's theorizing on religion and epistemology emerges, from this perspective, as the product of an embodied mind. The reconstruction of Durkheim's ten-year long sensuous process of writing the collection of texts that were to give origin to Formes has alerted us against readings that try to locate "the" crucial breakthrough in any one of those steps. Rather, Formes emerges from our study as the destiny location of the path Durkheim crossed in the company of his numerous associates, before his students, and in the solitude of his studio. Until the very end, Durkheim continued to theorize through the physical act of crafting the manuscript intended for publication. Once published, Formes (soon afterwards, Elementary Forms) gained a life of its own. In time, it became a totem for interpreters keen in using Durkheim's legacy to push for certain research agendas and disciplinary projects.

Twentieth century commentary on Elementary Forms took many forms. Each perspective on the meaning and import of Elementary Forms and its author to sociology, anthropology and religious studies had to establish itself against a number of competing others. From these struggles over the meaning of the work resulted explorations of different facets of Durkheim's message, from his political persuasion and methodological lessons to his theoretical contributions. Founded upon mutually incompatible epistemological assumptions, some of these visions of the sociological tradition are fundamentally at odds with others. Together they offer an overview of some of the main strategies of theory building employed in the discipline in the twentieth century. If one takes the materiality of the text seriously, though, a new approach to theory building emerges, one that is not only more sensitive to the ways in 
which Durkheim's theories were actually produced but also to the distinctively political character of the struggles over their meaning.

A crucial new theme of research emerges from this perspective. Durkheim's quest for the sacred unveils the sacred properties of objects in the secular domain. This is the case of objects endowed by human agents with special properties, both abstract objects, such as an idea one holds dear, and physical ones, say, a classic book. Alexander's genealogy of structuralism has unveiled a "subterranean" line of research from Saussure to Geertz exploring the late Durkheim's attention to culture, here equated with the deep structures of meaning that frame human agency (e.g. Alexander 1987: 281-329; 2001). Cultural sociology is the hermeneutic exercise of describing how agents work the binaries (civil vs. uncivil; authentic vs. artificial, etc.) that structure discourse. By contrast, our genealogy of Elementary Forms does not reduce the semiotics of the late Durkheim's theorizing to the realm of discourse, ideas or words. As Durkheim time and again emphasizes, physical things are part and parcel of the social world: they are as imbued with meaning as concepts or theories. ${ }^{30}$ This is clear from Durkheim's definition of religion: a "unified system of beliefs and practices relative to sacred things, that is to say, things set apart and forbidden - beliefs and practices which unite into one single moral community called a Church, all those who adhere to them." (1995: 44) $)^{31}$ A religion is thus a mode of action and a mode of thought, an attempt to classify things, relate them to one another within a certain explanation. For Durkheim, scientific thought is but a more elaborate form of religious thought; concepts are ideas that are both stable and impersonal and thus the product of a collective mind. The "categories of understanding" then are but concepts so stable and impersonal that we take them to be universal and immutable. Crucially, for Durkheim, these pre-eminent concepts by which all knowledge is constructed not only originate in 
social experience but are themselves the expression of social things. ${ }^{32}$ His conclusion, reached as he works through the pages of the draft in the weeks immediately prior to submitting it to the editor, is that these categories perform this permanent function because they must be based upon the physical world, a reality of equally permanent, pre-eminent status. Since nature cannot contradict itself, Durkheim reasons, the categories of understanding modeled on its realities must correspond to the basic, fundamental features of the physical environment: like religious thought, logical thought emerges out of social experience in a world of abstract and physical things, only a fraction of which is linguistic in nature.

Instead of forcing Durkheim to embark on a linguistic turn foreign to him and contrary to textual evidence, twenty-first century commentary should instead explore his semiotics of the sacred-profane in a more expansive fashion than postmodern thinking, with its exclusive emphasis on texts, allows. ${ }^{33}$ Texts are important. But texts are always the product of an embodied mind, whose activity - even, as Durkheim stressed, modern logical thought - is always irrevocably imbedded in the world of things. 
Bibliography

Alexander, Jeffrey C. Theoretical Logic in Sociology. 4 vols. Berkeley, CA: University of California Press, 1982-83.

— Twenty Lectures: Sociological Theory since World War II. New York: Columbia University Press, 1987.

— Durkheimian Sociology: Cultural Studies. Edited by Jeffrey C. Alexander. Cambridge: Cambridge University Press, 1988.

— The Performance of Politics. Obama's Victory and the Democratic Struggle for Power. New York, NY: Oxford University Press, 2010.

Alexander, Jeffrey C. and Philip Smith. "The Strong Program in Cultural Theory: Elements of a Structural Hermeneutics." Handbook of Sociological Theory, edited by Jonathan H. Turner, 135-150. New York: Kluwer Academic, 2001.

Alpert, Harry. Emile Durkheim and his Sociology. New York: Columbia University Press, 1939.

Aron, Raymond. The Main Currents of Sociological Thought, Vol. II: Durkheim, Pareto, Weber. New York: Basic Books, 1967.

Bachiocchi, Stéphane and Jean-Louis Fabiani. “Durkheim’s Lost Argument (18951955): Critical Moves on Method and Truth.” Durkheimian Studies 18 (2012): $19-40$.

Bellah, Robert N. "Civil Religion in America” Daedalus 96 (1967): 1-21. 
Besnard, Philippe. "La formation de l'équipe de L'Année sociologique,” Revue française de sociologie 20 (1979): 7-31.

— "Review of Durkheim et le politique," Revue Française de Sociologie 23 (1982): 127-130.

— (Ed.) The Sociological Domain: The Durkheimians and the Founding of French Sociology. Cambridge: Cambridge University Press, 1983.

Birnbaum, Pierre. 'La Conception Durkheimienne de l'Etat: L'Apolitisme des Fonctionnaires." Revue Française de Sociologie 17 (1976): 247-58.

Blau, Peter M. “Structural Effects.” American Sociological Review 25, no. 2 (1960): 178-193.

Borlandi, Massimo. "Présentation. Emile Durkheim: Les Formes élémentaires de la vie religieuse, un siècle après." L'Année Sociologique 62, no. 2 (2012): 283-288.

Camic, Charles and Hans Joas (eds.). The Dialogical Turn: New Roles for Sociology in the Postdisciplinary Age. Lanham: Rowman and Littlefield, 2003.

Cladis, Mark S. A Communitarian Defense of Liberalism: Émile Durkheim and Contemporary Social Theory. Stanford, CA: Stanford University Press, 1992.

— Durkheim and Foucault: Perspectives on Education and Punishment. Oxford: Berghahn, 1999.

— “Introduction," Elementary Forms of Religious Life, Émile Durkheim. Translated by Carol Cosman. Introduction and notes by Mark S. Cladis, vii-xxxv. Oxford: Oxford University Press, 2001. 
Cosman, Carol. “Note on the Text.” Elementary Forms of Religious Life, Émile Durkheim. Translated by Carol Cosman. Introduction and notes by Mark S. Cladis, xxxvi. Oxford: Oxford University Press, 2001.

Clark, Terry N. "Émile Durkheim and the institutionalization of sociology in the French university system," European Journal of Sociology 9 (1968): 37-71.

— Prophets and Patrons: The French University and the Emergence of the Social Sciences. Cambridge, MA: Harvard University Press, 1973.

Collins, Randall. "The Durkheimian movement in France and in world sociology," The Cambridge Companion to Durkheim, edited by J.C. Alexander and Philip Smith, 101-135. Cambridge: Cambridge University Press, 2005.

Coser, Lewis. Masters of Sociological Thought: Ideas in Historical and Social Context. New York: Harcourt Brace Jovanovich, 1971.

Durkheim, Emile. Division of Labor in Society. Edited with a new introduction by Steven Lukes. Translated by W.D. Halls. New York: Free Press, 2014. Originally published in 1893.

— The Rules of Sociological Method. New York: Free Press, 1966. Originally published in 1895 .

— Suicide. New York: Free Press, 1966. Originally published in 1897.

— “Concerning the Definition of Religious Phenomena." Durkheim on Religion, edited by W.S.F. Pickering, 74-99. Atlanta, Georgia: Scholars Press, 1994. Originally published in 1899 .

— “Sur le totemism.” L'Année sociologique 5 (1902): 82-121. 
— "Review of Pellison, Maurice. La Sécularisation de la moral au XVIIIe siècle." L’Année sociologique 8 (1905): 381-2.

— "La religion: les origins." Textes. Vol. 2, edited by Victor Karady, 65-122. Paris: Minuit, 1907.

— "Sociologie religieuse et théorie de la connaissance." Revue de métaphysique et de morale 17, no. 6 (1909): 733-758.

— Durkheim, Emile. Socialism and Saint-Simon. Edited with an introduction by Alvin Gouldner. Yellow Springs, Ohio: Antioch Press, 1958. Originally published in 1928.

Fernandes, Teresa Sousa. "Chemical Metaphors in Sociological Discourse. Durkheim Through the Imagery of Rousseau." Journal of Classical Sociology 8, no.4 (2008): 447-466.

Fields, Karen E. “Translator's Introduction: Religion as an Eminently Social Thing.” The Elementary Forms of Religious Life, Emile Durkheim. Translated by Karen E. Fields, xvii-lxxiii. New York: Free Press, 1995.

— "Translating Durkheim.” The Cambridge Companion to Durkheim, edited by J.C. Alexander and Philip Smith, 160-180. Cambridge: Cambridge University Press, 2005.

Filloux, Jean-Claude. Durkheim et le socialism. Geneva: Librairie Droz, 1977.

Fournier, Marcel. “Les Formes Élémentaires Comme Oeuvre Collective: Les Contributions d'Henri Hubert et de Marcel Mauss à la Sociologie de la Religion Tardive d'Émile Durkheim.” Canadian Journal of Sociology 39, no. 4 (2014): $523-546$. 
Frazer, James. Totemism. Edinburgh: Adam \& Charles Black, 1887.

Giddens, Anthony. Emile Durkheim. Selected Writings. Cambridge: Cambridge University Press, 1972.

— Emile Durkheim. New York: The Viking Press, 1979.

Glassman, E.H. The Translation Debate. What makes a Bible translation good? Downers Grove: Intervarsity Press, 1981.

Gouldner, Alvin. The Coming Crisis of Western Sociology. New York: Basic Book, 1970.

Habermas, Jürgen. The Theory of Communicative Action: Reason and the Rationalization of Society, Vol. 1. Translated by Thomas McCarthy. Cambridge: Polity, 1984. Originally published in 1981.

Hubert, Henri. "Étude sommaire de la représentation du temps dans la magir et al religion." Annuaire de l'Ecole Pratique des Hautes Etudes, Section des Sciences Religieuses (1905) 1-39.

Jones, Susan Stedman. Durkheim Reconsidered. Cambridge: Polity Press, 2001.

Jones, Robert Alun. "On understanding a sociological classic.” American Journal of Sociology 83, no. 2 (1977): 279-319.

— "Pragmatism and Protestantism in the Development of Durkheim's Sociology of Religion." Reappraising Durkheim for the Study and Teaching of Religion Today, edited by Thomas A. Idinopulos and Brian C. Wilson, 45-58. Leiden: Brill, 2001. 
Lacroix, Bernard. Durkheim et le politique. Paris: Presses de la Fondation Nationale des Sciences Politiques. 1981.

Levine, Donald N. Visions of the Sociological Tradition. Chicago: University of Chicago Press, 1995.

— "The variable status of the classics in differing narratives of the sociological tradition.” Journal of Classical Sociology 15, no. 4 (2015): 305-320.

Lukes, Stephen. Emile Durkheim, His Life and Work: A Historical and Critical Study. London: Allen Lane, 1973.

Martindale, Don. The Nature and Types of Sociological Theory. Prospect Heights: Waveland Press, 1981.

Mauss, Marcel. "Essai sur les variations saisonnières des sociétés eskimo: Étude de morphologie sociale." L'Année sociologique 9 (1906): 39-132.

McKinnon, Andrew. "Elementary forms of the metaphorical life: Tropes at work in Durkheim's theory of the religious.” Journal of Classical Sociology 14, no. 2 (2014): 203-221.

Miller, William Watts. A Durkheimian Quest: Solidarity and the Sacred. New York: Berghahn, 2012.

Morrison, Ken. "Book Reviews: The Elementary Forms of Religious Life, Free Press, 1995 and Oxford University Press, 2001.” Social Forces 82, no. 1 (2003): 399404.

Muirhead, John Henry. The Elements of Ethics: An Introduction to Moral Philosophy. New York: Charles Scribner's Sons, 1892. 
Nisbet, Robert. The Sociological Tradition. New York: Basic Books, 1966.

Park, Robert E. and Ernest Burgess. Introduction to the Science of Sociology. Chicago: University of Chicago Press, 1921.

Parsons, Talcott. Der Kapitalismus bei Sombart und Max Weber. InauguralDissertation zur Erlangung der Doktorwürde. Harvard University Archives, Parsons Papers, HUGFP 42.8.2, box 1, 1927.

— “'Capitalism' in Recent German Literature: Sombart and Weber.” The Journal of Political Economy, 36-37: 641-44; 31-51, 1928-1929. Reprinted in Talcott Parsons. The Early Essays, edited with an introduction by Charles Camic, 3-37. Chicago: The University of Chicago Press, 1991.

— The Structure of Social Action. New York: Free Press, 1968. Originally published in 1937.

Pickering, W.S.F. (ed.) Durkheim on Religion. Translated by Jacqueline Redding. London: Routledge, 1975

— Durkheim's Sociology of Religion: Themes and Theories. London: Routledge, 1984.

— Durkheim and Representations. London: Routledge, 2002.

Ricoeur, Paul. On Translation. London: Routledge, 2006.

Silva, Filipe Carreira. "Re-Examining Mead: G. H. Mead on the Material Reproduction of Society.” Journal of Classical Sociology 7, no.3 (2007): 291-313.

Smith, Philip and Jeffrey C. Alexander. “Review Essay: Durkheim’s Religious Revival.” American Journal of Sociology 102, no. 2 (1996): 585-592. 
Spencer, Baldwin and Francis J. Gillen. The Native Tribes of Central Australia. London: Macmillan, 1899.

Smith, Robertson. Lectures on the Religion of the Semites. Fundamental Institutions. First Series. London: Adam \& Charles Black, 1889.

Zeitlin, Irving. Ideology and the Development of Sociological Theory. Englewood Cliffs: Prentice Hall, 1968. 


\section{Annex}

\section{Complete list of editions of Elementary Forms consulted for this work}

1915. The Elementary Forms of the Religious Life. A Study in Religious Sociology.

Trans. Joseph Ward Swain. London: George Allen \& Unwin; New York: Macmillan Press. xi, 456 pages, $23 \mathrm{~cm}$. (Reprinted 1926, 1954, 1957, 1964)

1965. The Elementary Forms of the Religious Life. Trans. Joseph Ward Swain. Glencoe, IL: The Free Press. (first paperback edition)

1975. Durkheim on Religion. Trans. Jacqueline Redding. Ed. W.S.F. Pickering. London: Routledge. (Reprinted Atlanta: Scholars Press, 1994) (excerpts)

1976. The Elementary Forms of the Religious Life. A Study in Religious Sociology.

Trans. Joseph Ward Swain. London: George Allen \& Unwin; New York: Macmillan Press. $2^{\text {nd }}$ Edition. (Reprinted New York: Dover, 2008)

1995. The Elementary Forms of Religious Life. Trans. Karen Fields. Glencoe, IL: The Free Press.

2001. The Elementary Forms of Religious Life. Trans. Carol Cosman, Ed. Mark S. Cladis. Oxford: Oxford World's Classics. (Reprinted 2008) (abridged version) 2012. The Elementary Forms of the Religious Life. Trans. Joseph Ward Swain. Introd. Steven Alan Childress. New Orleans, La: Quid Pro Books, 2012. Centennial Edition. (available both in ebook and print formats) 


\section{Archives consulted for this work}

Archives nationales, 59 rue Guynemer, 93380 Pierrefitte-sur-Seine, Paris. Dossier Durkheim, F/17/25768.

Allen and Unwin Papers, University of Reading, United Kingdom.

\footnotetext{
${ }^{1}$ The main exception was Bellah (1967). Robert Bellah supervised Alexander's PhD.

${ }^{2}$ For the first claim, see the opinion survey on the most influential books for sociologists presented in ISA World Congress of Sociology held in Montreal 1998: http://www.isasociology.org/books/vt/bkv_000.htm; as to the second claim, see the six-part op-ed in the
} Guardian by Gordon Lynch in 2012-2013:

https://www.theguardian.com/commentisfree/belief/2012/dec/10/emile-durkheim-analysis-of$\underline{\text { moral-life }}$

${ }^{3}$ For a critical examination of the different narrative modes of the sociological tradition, including the "synthetic narrative" exemplified by Parsons and Alexander, see Levine (2015; 1995: 35-58).

${ }^{4}$ A task made possible by the historically minded scholarship of the "new Durkheim studies" of the 1970s. 
${ }^{5}$ It would be a mistake to consider Alexander's strong program in cultural sociology as a solitary intellectual endeavor expressed through academic publications alone. There is a pronounced institutional dimension to the program in cultural sociology, as evidenced first by the creation of the Center for Cultural Sociology at Yale in 2004, several book series in academic publishers, and more recently with the founding of the American Journal of Cultural Sociology.

${ }^{6}$ Alexander (1982: 478-9). Bernard Lacroix in Durkheim et le politique (1981) suggests the revelation of 1895 to have been the pivotal event after which Durkheim's relationship with religion and with his father changes irrevocably, while Besnard, in his review of Lacroix's book, sides with Alexander in suggesting that Durkheim's intellectual schema actually predates 1895.

${ }^{7}$ The idea of effervescence has a long yet chequered history in Durkheim's writings. On the metaphoric role of other chemical ideas such as aggregation, association, affinity, and combination in Durkheim's thinking, see Fernandes (2008); on the role of metaphors in shaping Durkheim's argument in Elementary Forms in general, see McKinnon (2014).

${ }^{8}$ In July 24, Durkheim writes to his friend and editor of the Revue de métaphysique et de morale, Xavier Léon: 'Vous savez peut-être que j'ai commencé la rédaction de mon livre sur les Formes élémentaires de la pensée et de la pratique religieuse.' (Durkheim 1975, vol. 2: 467) The draft has been published in the second volume of Victor Karady's 1975 anthology of Durkheim's texts as "La religion: les origins."

${ }^{9}$ Letter from Durkheim to Hubert, July 12, 1912. (cited in Borlandi 2012)

${ }^{10}$ The influence of Immanuel Kant over Durkheim through the work of the French neo-Kantians Charles Renouvier, Emile Boutroux, and Octave Hamelin is well-documented. See, e.g. Pickering (1984, 2002). 
${ }^{11}$ This co-written essay on the evolution from "primitive" to "modern" styles of thought is where Durkheim first extends French Neo-Kantianism into the direction of a groundbreaking sociology of knowledge (see e.g. Giddens 1978: 91; Jones 2000: 43ff.).

${ }^{12}$ The book is the fourth volume of the series 'Travaux de L'Année sociologique/'Bibliothèque de philosophie contemporaine,' edited by Durkheim himself. The first three volumes are all by other Durkheimians: Fonctions mentales dans les sociétés inférieures, by Lucien Lévi-Bruhl (1910), Mélanges d'histoire des religions, by Hubert and Marcel Mauss (1909), and Essais sur le régime des castes, by Célestin Bouglé (1908). The travels of the 1,650 copies of the first edition (a second would follow in 1925, a third in 1937) were about to begin. See the Global Reception's map at http://digitaldurkheim.hypotheses.org/1151 (last accessed: 22/08/2016) for a comprehensive database of all translations and covers of Durkheim's Formes élémentaires.

${ }^{13}$ Swain finishes his translation job in 1915 and, a year later, defends his doctoral dissertation at Columbia University on Hellenistic Influences on Christian Asceticism. Unsurprisingly, then, despite its many merits, Swain's translation work bears many marks of haste. (Fields 2005: 164) ${ }^{14}$ George Allen and Unwin Archive, Oxford, England; herewith GAUA.

${ }^{15}$ Letter from Swain to Allen and Unwin, October 14, 1914. GAUA.

${ }^{16}$ George and Allen and Unwin Archive, herewith GAUA.

${ }^{17}$ GAUA.

${ }^{18}$ According to Swain, Durkheim's first suggestion was “Totemism: A Study of the Elementary Religious Life." Durkheim then suggests a second title, which he tells Swain is the one he prefers: "Totemism: A Study in Religious Sociology." This is the title Swain uses in the manuscript he sends to the publisher.

${ }^{19}$ In a letter dated from May 21, Swain writes: "I must say that I am greatly mortified that my translation should be open to the criticisms which Professor Muirhead has made of it. In regard to the "solecisms of syntax," I presume that they bare largely "Americanisms" which sound strange to British people. Though I carefully went over my entire MS for the purpose of removing all such expressions, but it seems that I was not completely successful. The others 
cause of me greater shame for they seem to be simple blunders. However, I hope that they are not as numerous as Professor Muirhead's remarks would lead one to suppose. Will it be too late to change these if I carefully go over the entire proof again as soon as possible? I shall be only too glad to do so, if it will do any good." (GAUA) As it happens, no changes will be made and Swain's poor translation choices will plague this edition throughout its existence.

${ }^{20}$ Levine's description and analysis of the various narratives of the sociological tradition, although undoubtedly influential, suffers from at least one difficulty. The status of Levine's own "dialogical" narrative is problematic: although pluralistic in its character, it does not present itself in such terms. The label "pluralist" is left for the likes of Pitirim Sorokin or Dan Martindale. Yet what distinguishes Levine's pluralism from, say, Sorokin's is not a question of nature, but of degree - his pluralism was one that emphasized dialogue and mutual accommodation, as opposed to silence or conflict. "Dialogical pluralism" thus seems to be the most rigorous way to describe Levine's approach to the sociological tradition.

${ }^{21}$ See also Sorokin (1966: 280), where Elementary Forms is presented as an exemplar of a cultural systems theory.

${ }^{22}$ Whose disagreement with Parsons, as we have seen above, concerns the explanation for Durkheim's change and the timing of this change (1982: 471)

${ }^{23}$ But see Silva (2007).

${ }^{24}$ In fact, Durkheim's canonisation in sociology owes little to Elementary Forms. Illustrative in this regard is Anthony Giddens's (1972) Emile Durkheim. Selected Writings, which relegates Elementary Forms to a secondary position - only a few passages in the chapter on "Religion and ritual," itself one of thirteen chapters, the bulk of which devoted to methodology and division of labor in modern societies. By and large, it is around the middle-period works Suicide, Division of Labor and Rules that Durkheim, the master analyst of capitalist society is canonised in the end of the 1960s, early 1970s alongside Marx and Weber. Here is what Pickering had to say about Giddens's canonization efforts: "“Repeatedly one hears it said that the three men who contributed more than any others to sociology in the nineteenth century were 
Durkheim, Weber and Marx. If some may doubt the presence of Marx within the trinity and would prefer to see Simmel, Pareto or Spencer as the substitute, the fact remains that no one can dethrone Durkheim from being one of its members." (...) And he continues, pointing to an aspect that would prove absolutely central in Durkheim's reception in decades to come:

"However, there is one point that ought to be emphasised (...): the prominence that Durkheim gave to religion." (1975: 3)

${ }^{25}$ Such as the proponents of the strong program of cultural sociology, according to whom this new intellectual climate "has opened up a new breathing space for the later Durkheim," (Smith and Alexander 1996: 587)

${ }^{26}$ But see Ricoeur (2006) on the myth of "perfect translatability."

${ }^{27}$ Fields writes: "My purpose in undertaking a new translation is to re-represent Durkheim's ideas about what he called the 'religious nature of man' in the English of our own day while rendering Durkheim's French as faithfully as I can.” (1995: xxii)

${ }^{28}$ In contrast with Swain's which had very few by the translator himself, and expands Durkheim's often highly abbreviated references in the footnotes.

${ }^{29}$ In light of the previous section, however, such a claim seems to reflect more Alexander's own reading than the evolution of the readings in the discipline as a whole.

${ }^{30}$ This is not to say, of course, that the physical efficacy of the rite takes precedence over its moral or social efficacy. As Durkheim stresses in his discussion of the Wollunka, "a totem of a very special kind." This special status comes from the fact that the Wollunka, which natives imagine as colossal snake whose "head is lost in the clouds when it stands on its tale," is not a plant nor an animal, but a unique being - "a purely mythical being." (1995: 450) It is, in other words, a purely representative totem.

${ }^{31}$ Likewise, in his earlier definition of religion in "Concerning the Definition of Religious Phenomena" (1899), Durkheim argues that it consists of "obligatory beliefs united with definite practices which relate to the objects given in the beliefs." (1994: 93) 
${ }^{32}$ Durkheim writes: "the category of genus was at first indistinct from the concept of human group; the category of time has the rhythm of social life at its basis; the space society occupies provided the raw material for the category of space; collective force was the prototype for the concept of effective force, an essential element in the category of causality.” (1995: 441)

${ }^{33}$ Bachiocchi and Fabiani's (2012) exploration of the pragmatic dimension of the late Durkheim is a case in point. 